\title{
Investigation of compatibility between serological tests used in laboratory diagnosis of brucellosis
}

\author{
Brusellozun Laboratuvar Tanısında Kullanılan Serolojik Testler Arasındaki Uyumluluğun \\ Araştırılması
}

\author{
Selma Ay ${ }^{1}$, Bensu Güzel ${ }^{1}$, Yücel Duman ${ }^{1 *}$ \\ 1. İnönü Universty, Medicine Faculty, Depertamant of Medical Microbiology, Malatya, Turkey
}

\begin{abstract}
Aim: In the diagnosis of brucellosis, the production of microorganisms in blood or bone marrow culture is considered the gold standard. But it is not always possible to produce the microorganism. For this reason, serological tests are used to diagnose brucellosis. Rose Bengal test (RB), Standard Tube Agglutination test (STA), Coombs Test (CT) and 2-Mercaptoethanol (2-ME) tests are common methods. Immunocapture-agglutination test (ICA) and Brucella Coombs Gel test (BCGT) are tests that can detect blocking antibodies along with total antibodies. The aim of our study was to determine whether there is compatibility between the tests used in diagnosis and the ICA and BCGT tests.

Material and Methods: Serum samples were taken from patients with a preliminary diagnosis of brucellosis. RBT testing was performed primarily on all samples. Forty RBT positive and 40 RBT negative sera were included in the study. All serum samples were studied by STA, CT, 2-ME, ICA and BCGT methods. The compatibility between the tests were determined by using the kappa $(\mathrm{K})$ coefficient with the Cohen kappa analysis method.

Results: 28 of 40 patients with RBT positive were detected as positive with STA and 2-ME and 30 of them were positive with CT. BCGT and ICA test results were found positive in all RBT positive samples. All tests results were found to be negative in 40 RBT negative samples. Cohen Kappa analysis found that compliance between RBT and BCGT and ICA (Kappa $1.0<0.001$ ) was excellent. Compliance between STA, BCGT and ICA tests was found to be good (Kappa $0.7 p<0.001$ ). CT testing showed a very good level of compatibility between ICA and BCGT (Kappa $0.8 p<0.001$ ). There is a very good compatibility between the 2ME test, ICA and BCGT tests (kappa 0.7 0.001), Compliance between BCGT and ICA was also found to be very good (Kappa 1.0, p<0.001).

Conclusion: According to these results, with the use of ICA and BCGT tests, both the number of tests will be reduced and the time to receive results will be reduced. But further studies are needed to determine the sensitivity and specificity of these tests based on culture results. But after that, we believe it can be used as a diagnostic test.

Keywords: Brucellosis, Standard Tube Agglutination test, Coombs Test, Brucella Coombs Gel test, Immunocapture-agglutination test
\end{abstract}

\section{öz}

Amaç: Bruselloz tanısında altın standart kan veya kemik iliği kültüründe mikroorganizmanın üretilmesi olarak kabul edilmektedir. Ancak mikroorganizmay üretmek her zaman mümkün olmamaktadır. Bu nedenle Bruselloz tanısı için serolojik testler kullanilır. Rose Bengal testi (RB), Standart Tüp Aglütinasyon testi (STA), Coombs Testi (CT) ve 2-Merkaptoetanol (2-ME) testleri yaygın yöntemlerdir. Immünokaptur-aglütinasyon testi (ICA) ve Brucella Coombs Jel testi (BCGT), toplam antikorlarla birlikte bloke edici antikorları tespit edebilen testlerdir. Çalışmamızın amacı tanıda kullanılan testler ile ICA ve BCGT testleri arasında uygunluk olup olmadığını belirlemektir.

Gereç ve Yöntemler: Bruselloz ön tanısı olan hastalardan serum örnekleri alındı. Öncelikle tüm numunelerde RBT testi çalışıldı. Çalışmaya 40 RBT pozitif ve 40 RBT negatif serum dahil edildi. Tüm serum örnekleri STA, CT, 2-ME, ICA ve BCGT yöntemleriyle çalışıldı. Testler arasındaki uyumluluk kappa $(\mathrm{K})$ katsayısı kohen kappa analiz yöntemi kullanılarak belirlendi.

Bulgular: RBT pozitif olan 40 hastanın 28'i STA ve 2-ME ile pozitif, 30'u BT ile pozitif bulundu. BCGT ve ICA test sonuçları tüm RBT pozitif örneklerde pozitif bulundu. Tüm test sonuçları 40 RBT negatif numunede negatif bulunmuştur. Kohen Kappa analizi, RBT ile BCGT ve ICA (Kappa 1.0, $p<0.001$ ) arasındaki uyumun mükemmel olduğu bulundu. STA, BCGT ve ICA testleri arasındaki uyumun ise iyi düzeyde olduğu belirlendi (Kappa 0.7, $p<0.001$ ). CT testi, ICA ve BCGT arasında çok iyi uyumluluk seviyesi gösterdi (Kappa 0.8, $p<0.001)$. 2ME testi, ICA ve BCGT testleri arasında uyum çok iyi olarak değerlendirildi (kappa $0.7, p<0.001)$, BCGT ve ICA arasındaki uyumun da çok iyi düzeyde olduğu saptandı (Kappa 1.0, $p<0.001$ ).

Sonuç: Bu sonuçlara göre ICA ve BCGT testlerinin kullanılmasıyla hem test sayıs azalacak hem de sonuç alma süresi kısalacaktır. Ancak bu testlerin duyarlıı̆ını ve özgüllüğünü kültür sonuçlarına göre belirlemek için daha fazla çalışmaya intiyaç vardır. Ancak ondan sonra, teşhis testi olarak kullanılabileceğine inanıyoruz.

Anahtar Kelimeler: Bruselloz, Standart Tüp Aglütinasyon testi, Coombs Testi, Brucella Coombs Jel testi, İmmünokaptur-aglütinasyon testi

Received: 15.02.2021 Accepted: 26.03.2021 Published (Online): 30.08.2021

*Corresponding Author: Yücel Duman. Tıbbi Mikrobiyoloji AD, İnönü Üniversitesi, Tıp

Fakültesi, Malatya, Türkiye, +905355596696, yucel.duman@inonu.edu.tr

ORCID: 0000-0002-9090-2096

To cited: Ay S, Güzel B, Duman Y. Investigation of compatibility between serological tests used in laboratory diagnosis of brucellosis Acta Med. Alanya 2021;5(2):171-174 doi:10.30565/medalanya.880738 


\section{INTRODUCTION}

B rucellosis is a zoonosis that is caused by bacteria of the genus Brucella, which is common in humans and animals. The disease is often transmitted to people as a result of oral ingestion of contaminated food and contact with contaminated material $[1,2]$.

Production of microorganisms in culture is the gold standard in brucellosis diagnosis. However, it is not always possible to produce the microorganism and for this reason, serological tests are used in the diagnosis of brucellosis. The Rose Bengal test (RBT), the standard tube agglutination test (STA), the Coombs test (CT) and the 2-merkapto ethanol test (2-ME) are often used in routine laboratories [1-3]. Aside from the RBT, the working time of these tests is long, the evaluation being carried out after 24 to 48 hours. Due to their specificity and sensitivity, which vary from one to the other, it is recommended that tests be used in combinations. For this reason, studies are continuing to develop simple, shorter-term diagnostic methods. Immunocapture agglutination (ICA) and the Brucella Coombs Gel Tests (BCGT) are agglutinationbased tests that can detect blocking antibodies as well as total antibodies. The ICA test results can be obtained in 24 to 48 hours, while the BCGT results are obtained on the same day and in as short as 2 hours $[4,5]$. By using these, the number of tests will be reduced, as well as the time to obtain results. It was aimed in this study to determine whether there is compliance between the ICA test and BCGT with the routinely used methods.

\section{MATERIAL AND METHODS}

Serum samples of pre-diagnosed brucellosis patients sent to the microbiology unit of the TOTM Central Laboratory of Inonu University Faculty of Medicine, were included in the study. 40 RBT positive and 40 RBT negative samples were included in the study. In all samples, RBT (Seromed, Istanbul), STA (Seromed, Istanbul), 2-ME and CT (Seromed, Istanbul) tests were studied first. For RBT, one drop of antigen was dripped on one drop of patient serum. Agglutination after rotation was considered positive. For STA, serum samples were diluted to be final titer $1 / 1280$. Antigen was added on it and incubated at 37 degrees. After 24 hours, the tubes were evaluated for agglutination. Titers $1 / 160$ and above were considered significant. 2-ME test is a semi-quantitative tube agglutination test. 2-ME neutralizes IgM type antibodies. Afterwards, the IgG antibodies in the serum combine with the antigen and become agglutinated. CT is a semiquantitative tube agglutination method. In this test, blocking antibodies bind with anti-human immunoglobulins added to the serum and a visible agglutination appears. Titers $1 / 160$ and above were considered significant $[1,2]$.

ICA (Vircell Brucella Capt test, Porque Technologica, Spain) consists of U-bottomed well strips coated with anti-human immunoglobulins. For this test, patients' serums were diluted. The antigen was added and incubated for 18-24 hours until agglutination occurs in the well strips. If there were no Brucella antibodies in the serum, the antigens appeared as blue dots and those that collapses to the bottom were considered negative. A homogeneous image attached to the inner surface of the well strips was evaluated as positive. BCGT (ODAK Brucella, Toprak Medical, Istanbul) is a method of agglutination that occurs in the wells containing gel matrix and coombs antibodies. The test was attempted according to the manufacturer's recommendations. At the end of the incubation, the results were evaluated visually. If there are no Brucella-specific antibodies, Brucella antigens appear pink at the bottom. If there is an antibody specific to Brucella, the antigen-antibody complex appears pink at the top of the gel [5]. The compatibility between the tests were determined using the Cohen Kappa analysis method and the Kappa ( $K$ ) coefficient $(\mathrm{k}=0.61-0.80$ good compatibility, $\mathrm{K}=0.81-1.00$ very good compatibility) [6]. Analysis were made by using the IBM SPSS Statistics for Windows version 25.0 (NY, USA).

\section{RESULTS}

A total 28 of the 40 RBT positive patients were positive with STA and 2-ME, and 30 were positive with CT. BCGT and ICA test results were found as positive in all RBT positive samples. STA, CT, 2-ME, BCGT and ICA tests were also found to be negative in 40 serum samples that were RBT negative. Distribution of the test results 
of 80 samples is given in the Table 1. Cohen Kappa analysis was performed to determine the compatibility between the tests. Compliance between ICA and BCGT with the RBT was very good ( $k 1.0 \mathrm{p}<0.01)$. It was determined that compliance was good between the ICA and BCGT tests with the $2-M E$ test $(k 0.7 p<0.01)$. Compliance between ICA and BCGT was observed to be good with the STA test $(k 0.7 p<0.01)$. A very good level of compliance was found between ICA and BCGT tests with CT test (Kappa $0.8 p<0.01$ ). Compliance between BCGT and ICA was also found to be very good (Kappa 1.0 p <0.001). Compliance between the tests (kappa coefficient) is given in the Table 2.

Table 1. Distribution of the test results of 80 samples

\begin{tabular}{|l|l|l|l|}
\hline TEST & Positive $\mathrm{n}(\%)$ & Negative $\mathrm{n}(\%)$ & Total $\mathrm{n}(\%)$ \\
\hline RBT & $40(50)$ & $40(50)$ & $80(100.0)$ \\
\hline STA & $28(35)$ & $52(65)$ & $80(100.0)$ \\
\hline CT & $32(40)$ & $48(60)$ & $80(100.0)$ \\
\hline $2-M E$ & $28(35)$ & $52(65)$ & $80(100.0)$ \\
\hline BCGT & $40(50)$ & $40(50)$ & $80(100.0)$ \\
\hline ICA & $40(50)$ & $40(50)$ & $80(100.0)$ \\
\hline
\end{tabular}

Table 2. Compliance between the tests (kappa coefficient)

\begin{tabular}{|l|l|l|}
\hline & Kappa & $\mathrm{p}$ \\
\hline RBT - BCGT & 1,0 & $<0,001$ \\
\hline STA - BCGT & 0,7 & $<0,001$ \\
\hline CT - BCGT & 0,8 & $<0,001$ \\
\hline 2ME Test - BCGT & 0,7 & $<0,001$ \\
\hline RBT- ICA & 1,0 & $<0,001$ \\
\hline STA - ICA & 0,7 & $<0,001$ \\
\hline CT- ICA & 0,8 & $<0,001$ \\
\hline 2ME Test -ICA & 0,7 & $<0,001$ \\
\hline BCGT - ICA & 1,0 & $<0,001$ \\
\hline
\end{tabular}

BCGT: Brucella Coombs Gel Test, ICA: Immuno Capture Agglutination Test, CT: STA with Coombs, STA: Standard Tube Agglutination Test, 2ME: 2-Mercaptoethanol Test, RBT: Rose-Bengal Test. ( $\bigotimes=0,61-0,80$ good compliance, $\bigotimes=0,81-1,00$ very good compliance)

\section{DISCUSSION}

Culture, serology and molecular methods are used in laboratory diagnosis of brucellosis. A definitive diagnosis is done by isolating bacteria from blood or bone marrow and other tissues and body fluids. Production of bacteria in culture varies between $15-70 \%$ according to the period of disease, whether antibiotics are used or not [1, 2]. For this reason, serological tests are used in diagnosis. The sensitivity of the RBT has been reported at over $99 \%$. It has been emphasized that it can be used as a screening test, and that positive results must be verified by other tests [13]. Total antibodies (IgG, IgM, IgA) are detected together in the STA test. Above 1/160 titters with clinical symptoms are considered positive. Demonstration of seroconversion is diagnostic. Because of the blocking antibodies found in chronic cases, CT testing should also be done and blocking antibodies should be revealed [5, 7-9].

ICA is a test that can be obtained within 18 to 24 hours based on immune capture and can detect blocking antibodies, along with total antibodies. It has been reported that it can be used to determine the activity of infection [4]. BCGT is a test produced in our country, based on agglutination, which can detect blocking antibodies along with total antibodies [5]. Ivrem and colleagues [10] reported a perfect match between the STA and CT ( $\mathrm{k} 0.887$ ) and between the CT and BCGT (k 0.977). Koroglu and colleagues [11] reported a very good level of compliance between the CT and ICA, between the CT and BCGT ( $k 0.844 p<0.001)$ and between the ICA and BCGT (k 0.802 p<0.001). Turk Dagı and colleagues [12] determined that the BCGT test had a similar performance to the serological tests used in the diagnosis and follow-up of brucellosis. Orduno and colleagues [13] reported very good performance between ICA and STA and good performance between ICA and CT. Kaya and colleagues [14] reported that BCGT can be used in diagnosis of brucellosis because it gives results in a short time and visual evaluation is facilitated. Gündem and colleagues [15] emphasized that ICA testing is an effective diagnostic method because it shows blocking antibodies. In our study, Cohen Kappa [6] analysis was used to determine compliance between the tests we use in routine and the BCGT and ICA tests. Good compatibility between STA and ICA ( $0.7 p<0.01)$, very good compatibility between CT and BCGT and ICA (k $0.8 p<0.01$ ), very good compatibility between $C T$ and BCGT and ICA ( $\mathrm{k} 0.8 \mathrm{p}<0.01)$ and compliance between BCGT and ICA was found to be very good (Kappa 1.0 p<0.001) (Table 2).

According to our results, performance values between tests are similar to those reported by other researchers. In the ICA method, the results are evaluated at the end of incubation for 18 to 
24 hours. BCGT test results are received on the same day and in less than 2 hours. In our study, compliance between ICA and BCGT tests was also found to be very good. For this reason, ICA or BCGT tests will provide ease of operation, as well as shorten the analysis time, therefore it will also allow practitioners to begin treatment early. The BCGT test appears to be the primarily preferred test for diagnosis due to fact that the results can be obtained on the same day and in a time as short as 2 hours. However, together with the culture results, the sensitivity and specificity of the BCGT test should be determined and we believe it would be appropriate to use it as a routine test from now on.

Conflict of Interest: The author has no conflict of interest related to this article.

Ethics Committee Approval: The study was approved by the Inonu University Clinical Research Ethics Committee (No:2017/18-1).

Funding sources: This work was supported by Inonu University Scientific Research Projects Coordination Unit with Project Number 2017-843.

Peer-review: Externally and internally peer reviewed.

\section{REFERENCES}

Peterson JM, Schriefer ME, Araj GF, veralovic J, Karoll KC, Funke G, Jorgensen JE Landry ML Wamock DW editors. Francisella and Brucella In: Manuel of Clinical Microbiolgy. 10th. E. Washington DC; 2011.p.751-69.

2. Pappas G, Akritidis N, Basilkovski M, Tsianos E, et al. brucellosis. N Engl J Med. 2005;352(22):2325-36. PMID: 15930423

3. Dean AS, Crump L, Greter H, Shcelling E, Zinsstag J, et al. Global burden of human brucellosis.a systematic rewiev of disease frquency. Plos Negl Trop Dis. 2012:6(10):e1865. PMID: 23145195

4. Özdemir M, Doğan M, Baysal B. A new method in the diagnosis of Brucellozis: Immuncapture agglutination test. Genel Tip Der. 2007;17(1):9-13.

5. Brucellacapt. http://peramed.com/peramed/docs/BRUCAPT_TR.pdf erişim; 16 Aralık 2020

6. Alpar R. Spor, Sağlık ve Eğitim Bilimlerinden Örneklerle Uygulamalı İstatistik ve Geçerlik-Güvenirlik. 1st ed. Ankara: Detay Yayıncılık. 2010. p. 189-218.

7. Diaz R, Casnova A, Ariza J Moriyon I, et al. The Rose-bengal test in human brucellosis: a negleted test fort the diagnosis of negleted Disease. PLOS Negl Trop Dis. 2011:5(4):e950. PMID: 21526218

8. Dağlar DE, Baysan BE. Diagnostic Methods of Brucella infection diagnosis in humans. İnönü Üniv Sağlık Bil Derg. 2014;3(2):46-48.

9. Dhauk SA, Nöckler K. Implication of Laboratory diagnosis on brucellosis therapy Expert Rew Anti Infect Ther. 2011:9(7):833-45. PMID: 21810055

10. Ivrem A, Yücel FM, Aksaray S, Bor E, et al. Comparison of a New and Rapid Meth od, Brucella Coombs Gel Test With the Other Methods in the Serological Diagnosis of brucellosis. Mikrobiyol Bul. 2015;49(2):182-187.

11. Köroğlu M, Akkaya AÖ, Demiray T, Erkorkmaz U,Özbek A, Alındiş M, et al. Comparative evaluation of the Brucella Coombs Gel test in laboratory diagnosis of human brucellosis. Biotehnol and Biotechnological Equip. 2016;30(6):970-5 DOI: 10.1080/13102818.2016.1190945

12. Tük Dağı H, Fındık D. Bruselloz tanısında yeni bir yöntem: Brucella Coombs Gel test. Genel Tip Derg. 2016;26(1):19-22.

13. Orduña A, Almaraz A, Ana Prado M, Gutierrez P, Pascual AG, Dueñas A, Cuervo M, Abad R, Hernández B, Lorenzo B, Bratos MA, Torres AR, et al. Evaluation of an Immunocapture Agglutination Test Brucellacapt) for Serodiagnosis of Human brucellosis. J Clin Microbiolgy. 2000;38(11): 4000-5. PMID: 11060059

14. Kaya M, Kurtoğlu MG, Güzelant A et al. The Comparison of Brucella Gel Agglutina-

tion Test with Other Serological Tests for the Diagnosis of brucellosis. Selçuk Med J. 2018:34(1):1-5. DOI: 10.30733/std 2018.00987

15. Gündem NS, Kalem F. Evaluation of results of Rose Bengal, Standard Tube Agglutination and Brucellacapt in brucellosis suspected cases. Genel Tıp Dergisi. 2015; 25:46-51.

\begin{tabular}{|l|l|}
\hline Author/ORCID & Authorship Contrubition \\
\hline $\begin{array}{l}\text { Selma Ay } \\
0000-0002-7640-6635\end{array}$ & $\begin{array}{l}\text { Consept, design, materials, data collection; } \\
\text { Interpretation, literature search, manuscript } \\
\text { writing, final approval }\end{array}$ \\
\hline $\begin{array}{l}\text { Bensu Güzel } \\
0000-0002-9156-2556\end{array}$ & $\begin{array}{l}\text { Data collection, materials, Interpretation. } \\
\text { literature search, manuscript writing, final } \\
\text { approval }\end{array}$ \\
\hline $\begin{array}{l}\text { Yücel Duman } \\
0000-0002-9090-2096\end{array}$ & $\begin{array}{l}\text { Design, Analysis, Interpretation, Final } \\
\text { approval, Supervision, critical review }\end{array}$ \\
\hline
\end{tabular}

